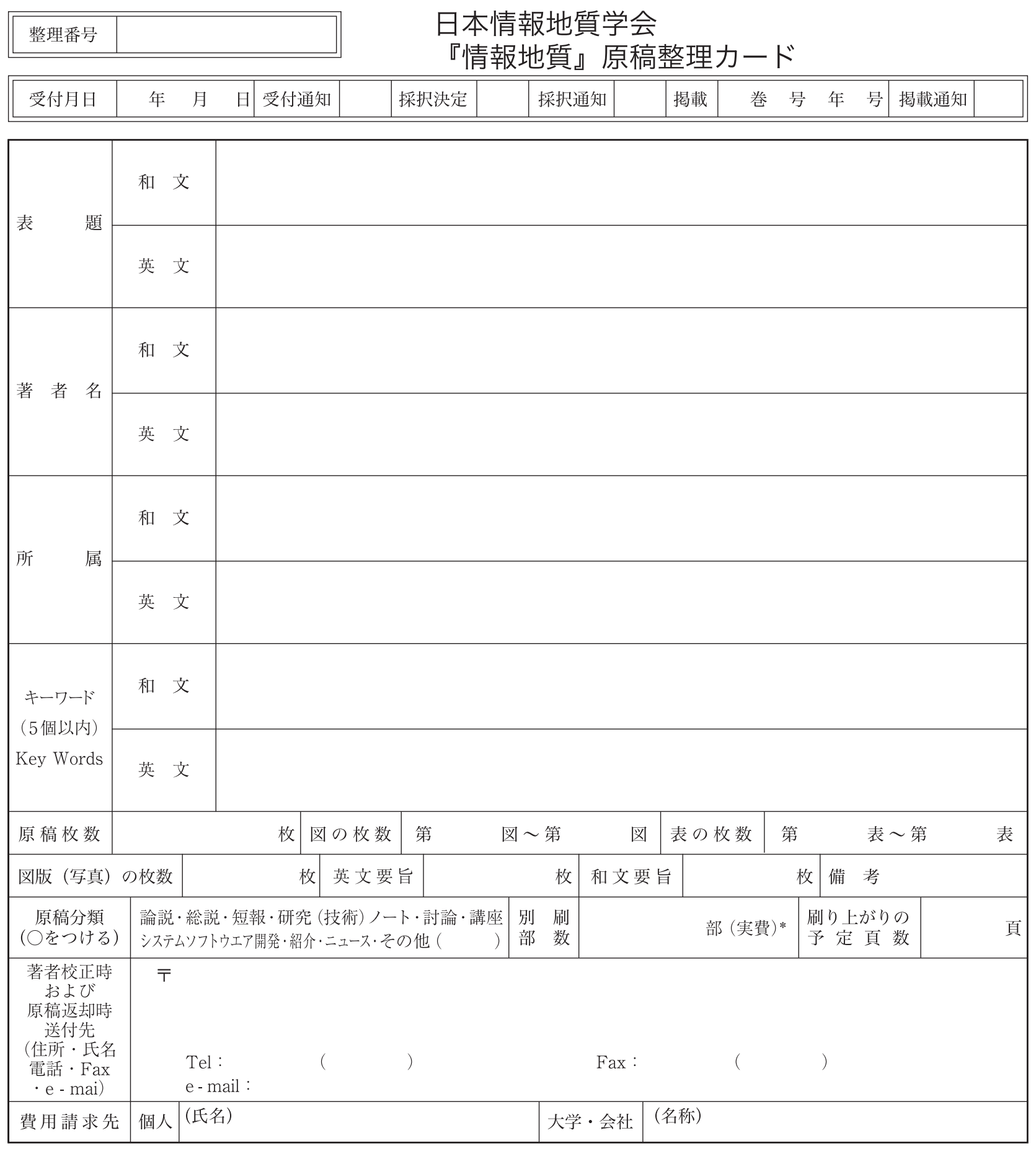

\title{
承諾 書
}

日本情報地質学会 会長 殿

年日

私は、本原稿が「情報地質」に受理された際は，本著作物の著作権を日本情報地質学会に譲渡いたします，本著作物が 共同執筆の場合，私は全著者を代表して本承諾書に記名・押印いたします。

$$
\begin{gathered}
\text { 住 所 } \\
\text { 氏 名 }
\end{gathered}
$$

(注)二重枠内は編集委員会の記入欄 $*$ 別刷の制作費は著者負担です. 作成希望の方は編集委員会にご相談ください. 


\section{保 証 書}

年月日

著作者（代表者）氏名

印（自筆署名の場合，押印は省略可）

住所

原稿表題

署名者が代表する共著者す心゙ての氏名*

著作者（代表者）は，日本情報地質学会発行の「情報地質」に投稿した上記表題の原稿（著作物）につ いての下記各事項を保証し, 確約します.

1）本著作物が著作者のオリジナルな著作物であり, 既にいずれかで出版公表されていたり，出版公表予 定でないこと.

2） 本著作物が既存の出版公表物などに対する知的財産権へのいかなる侵害も含まぬこと.

3） 本著作物中に他から転載されている全ての図表について，転載許可を得ていること.

4）本著作物中, 他の論文等の引用がある場合には，当該引用が公正な慣行に合致し，目的上正当な範囲 内であること。

5）著作物には，日本情報地質学会の名誉を傷つけ，情報地質の信用を毀損する盗用データ，捏造データ， 著作物に関する利害を持つ者の合意に反するものを含まないこと.

6）本著作物が共同著作物である場合には，代表して本保証書に署名捺印する者が，全ての共著者から， 本保証書に署名捺印寸ることについて同意ないしは必要な権利を得ていること.

7）本著作物についての問い合わせ, 苦情, 紛争などが発生した場合, 署名者はすべての責任を負うこと.

* 著作者名中に団体名を含む場合には，その団体に著作権が発生し，構成メンバー個々人には著 作権が分与されません.構成メンバー全員に平等に著作権が分与されることを希望する場合は, 原則として，全員の氏名を列挙する必要があります．また，著作に法人等の業務に従事する者 が関与しているときは，当該法人等が共同著作者となる場合（著作権法 15 条 1 項）がありま すのでご注意ください.

以上

本保証書の書式をコピーし, 必要事項を記述したうえで, 投稿原稿とともに編集委員会へ送付下さい. 本保証書への署名がないと，原稿の受付ができません．

保証書は日本語版（正本）と英語版の 2 種類があります。いずれか一つをお送りください.

学会記入 原稿受付番号觉付日 年 月 
日本情報地質学会入会申し込み書

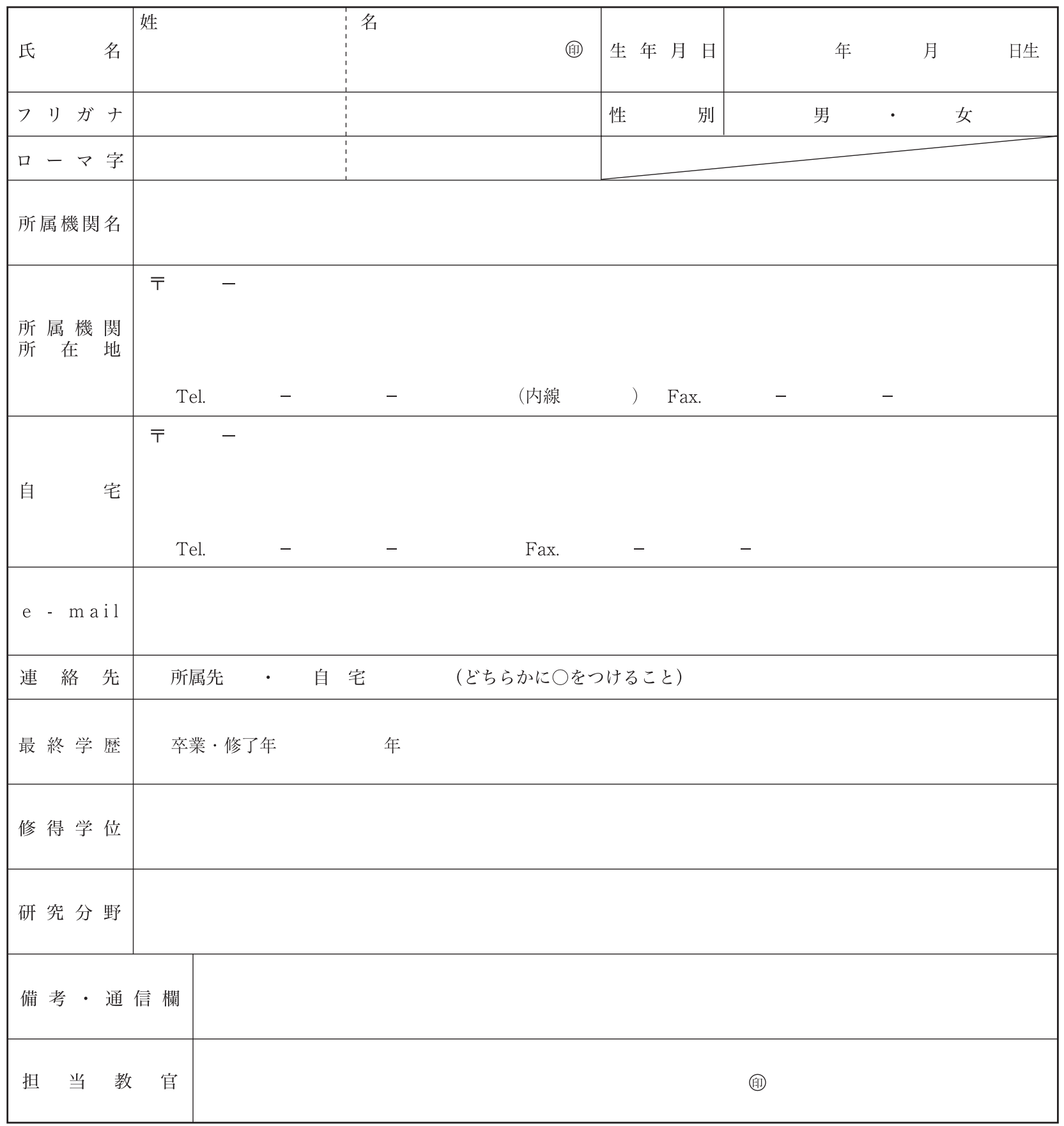

記入にあたっては裏面の記入要領を参照してください。

申し込み書提出とともに会費を納入してください。

学生会員の申し込みには担当教官の署名・捺印が必要です。

T225-0003 神奈川県横浜市青葉区新石川3-22-1＼cjkstart国学院大学人間開発学部内

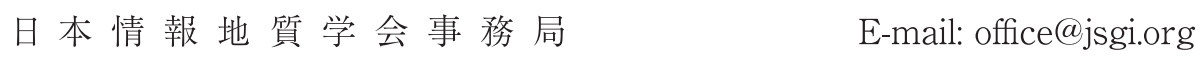

以下の欄には記入しないでください。

$\begin{array}{lll}\text { 受付年月日 会費承認年月日 } & \text { ID }\end{array}$ 


\section{入会申し込み書 記入要領}

1. 欄はすべて記入して下さい. 記入事項はコンピュータに登録しますので, 楷書ではっきり記入して下さい.ゴム印 等を用いられても結構ですが，かすれないように注意して下さい

2. 団体で加入される場合は, 担当の方の氏名等を記入し, 備考欄に「団体」と記入して下さい. 入会後, 担当者が変 更の場合にはただちに事務局に抢知らせ下さい，なお，賛助会員の入会申し込みは別案内をさしあげますので，こ の用紙で申し込まないように打願いします。

3. 所属機関の名称は原則として, 大学の場合は学部・学科まで, 会社などの場合は部・課まで記入して下さい. 学生 の方は学年まで記入して下さい.

4. 自宅，所属機関㧍よびその所在地など，読みにくい漢字にはフリガナをつけて下さい．

5. 自宅・所属先ともに，ファクシミリが使用できる方はできるだけ番号を記入して下さい.

6. e-mail のアドレスは学会からの配信メールを受け取れるものをご記入下さい.

7. 連絡先は希望される方に○をつけて下さい.

8. 最終学歴は卒業年, 最終卒業学校 (学部・学科) 名を記入して下さい.

9. 研究分野は学科名・部署名でなく, 研究内容 (担当内容) を書いて下さい.

10. 学生の方は在学証明のために, 担当教官の署名・捺印をもらって下さい.

入会申し込み書提出とともに, 会費を納入して下さい.

会費は正会員 5,000 円です。ただし，学生は 2,500 円です.

入会は, 申し込み書提出・会費納入を確認した後, 評議員会で承認されます.

（注）入会申し込み書記入事項に変更があった場合はただちにご連絡下さい.

学会事務局ならびに入会申し込み書送付先

日本情報地質学会事務局

～225-0003 神奈川県横浜市青葉区新石川 3-22-1

国学院大学人間開発学部内 日本情報地質学会事務局

E-mail: office@ jsgi.org

\section{会費振込先}

郵便振替：口座番号：00920-1-33834

口座 名: 日本情報地質学会

銀行振込：りそな銀行 我孫子支店（店番：１３１）

口座番号：5021778（普通口座）

口座名: 日本情報地質学会

（銀行振込をご利用の場合は，振り込んだ内容をお知らせ下さい） 


\section{編 集 後 記}

この度，日本情報地質学会の学会誌「情報地質」の編集長を小池克明先生から引き継ぎました海洋研究開発機構の 木戸ゆかりです，歴代の編集長のご業績を見ますと，あまりにも大役を仰せつかり，軌道に乗せることができるだろ うか, と引き継ぎ資料を見ながら思っております。しかし，たいへん心強いことに，長年本業務にご尽力されていらっ しゃる塩野清治先生，新たに能美洋介先生に副編集長として入っていただけることとなり，この3名の幹事体制にて 運営してまいります。

本号では，産業技術総合研究所の西岡芳晴氏による「システム・ソフトウェア開発：ウェブアプリケーションで 点群を高速に扱うための仕様“点群PNG”の考案」記事をお届けします。点群PNGを用いて大量のポイントデータ を極めて小さなファイル容量に収めることで高速処理の可能性を示されました，実装試験も済み，完成度が高く， WebGLでの活用が期待されます。インドネシアのハサヌディン大学の Asran Ilyas 氏からは,「研究紹介：Introduction of a Geoinformatic Research on Resource and Reserve Estimations of Laterite Nickel Deposit at Hasanuddin University (Indonesia)」の記事を寄稿いただきました。そして本学会第 17 期の開始にあたり小池克明 新会長からの「新情報地 質学：まだ見ぬ新たな領域を目指して」という学会員への明確なメッセージを合わせて掲載します。新型コロナウィ ルス感染症拡大防止のため, 昨年からGeoinforum総会・評議会はオンラインとなり，対面でのイベントが制限され ております。会場にて新会長から直接メッセージを聞くことができず残念ですが，課題のリストを見ながら当学会誌 の役割を考えてみたいと思います.

私の情報地質学会との思い出は, 初めて卒業論文が受理掲載されたことから始まります。日本周辺の海底地形図作 成のためのお絵描きソフトの開発といった内容でした。当時，大型計算機室の大判のXYプロッターで描き出される 海岸線，等深度線の形状にワクワクしたのを覚えています。お絵描きソフトは，船上のPCにも移植し，摇れるブリッ ジで縦横に多色ペンが動き, 海底地形図が描かれるのを眺めては海底へのイメージを膨らませました。それから 35 年. 計算機・測深機器等のスペックは，当時では信じられないほどに進化し，今や自走・自律型ロボットが，制限時間内

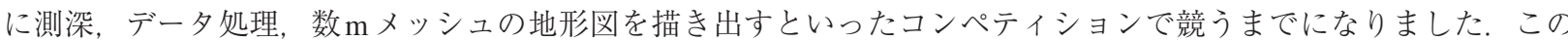
ように計算機科学, 数值地形学, 応用地質学など本学会の守備範囲はとても広く, 小池新会長が書かれているように, 1 学会で GIS ·地質モデリング・論理地質学, データベース, データ標準化・管理,リモートセンシング, 自然災害 情報, 地球統計学的空間モデリング, 情報解析, 地球物理・化学, 地学教育と多岐にわたるという特長があります. そして多分野に関わる官・民・学・教育界に所属される年齢層の広い学会員で構成されています。時代の流れや社会 のニーズ，そして情報処理の染化と共に分野の幅も広がり，深まってまいりました。コロナ渦でフィールド調査や 海洋調査が思うようにできない年を経験しましたが，今こそ，情報地質の記録を残し，デー夕整理，高機能デー夕 ベース，VRを取り入れた可視化等に時間・労力を費やせるのではないか，と感じています。当学会誌は，J-STAGE， Journal@rchive（2012 年以降J-STAGEへ統合），CiNiiによる公開を行なってきました。 これは，幅広い読者に活用さ れ情報地質学分野の普及，発展に貢献することを目指したものです。会長の示された今後の課題の一つに「学会誌の さらなる充実」があります。昨今の学会誌や研究データのオープンアクセス化の波に対応し，多岐にわたる分野横断 型の当学会の特色を生かし魅力ある学会誌を目指したいと思います．皆様の研究・技術開発の成果や進渉の発表や研 究室紹介など，どしどしご寄稿ください，査読のお願い時には，是非ともお引き受けください，学会員の皆様へご協 力をお願いし、新情報地質学の発信源として取り組んでまいります。どうぞよろしくお願いいたします。 